\title{
Fear and Loathing in Amritsar: an Intimate Account of Colonial Crisis
}

\author{
KIM A. W A G NER* \\ E-mail: k.wagner@qmul.ac.uk
}

This essay revisits the events surrounding one of the most emblematic instances of colonial violence, namely the Amritsar Massacre of 1919, through the diary of an Englishwoman, Mrs. Melicent Wathen. Where most histories of the Amritsar Massacre emphasize British brutality and Indian suffering, Melicent's experience was instead characterized by fear and the uncertainty of what became a headlong flight from Empire. Her diary thus offers an intimate account of colonial crisis. If we are to engage comprehensively with the lived experience of empire, the forms and functions of colonial fears and anxieties must be acknowledged; not because colonial panics were caused by real threats, which often they were not, but because they played such a crucial role in shaping colonial policies and in framing the relationship between rulers and ruled.

Keywords: Amritsar, Violence, Anxiety, Fear, Gender.

"We cannot be very brave unless we be possessed of a greater fear."

-Brig.-General R. E. H. Dyer, 1919

"To her mind the words 'sedition', 'Nationalism', 'rebellion', 'Home Rule', conveyed
one thing and one only, and that was a picture of herself being raped by a procession
of jet-black coolies with rolling white eyeballs. It was a thought that kept her awake at
night sometimes."

George Orwell, Burmese Days (1934)

The prospect of losing one's mind or 'going native'; succumbing to heat and illness; rumours, rebellion and the questionable loyalty of native servants; the sexual threats to white women by men of colour; miscegenation and the breakdown of racial barriers - this was the stuff of which colonial nightmares were made. ${ }^{1}$ Such concerns did not simply affect high-strung individuals at the margins of empire, but were equally pervasive in the imperial metropoles. From the 'Mutiny' to the Mau Mau, from 
Kipling to Conrad and beyond, fear and anxiety were at the heart of the colonial experience. ${ }^{2}$ Imperialism could in and of itself be seen to trigger strong psychological responses in colonisers and colonised alike. Being cut off from civilization and their fellow white men might cause Europeans to 'go Fantee', while too much civilization, too soon, would make 'natives' run amok. ${ }^{3}$ Defying easy diagnosis, the mental strain, or 'nerves,' suffered by colonisers was often medicalized under the vague nomenclature of 'tropical neurasthenia,' or its geographically specific equivalents, 'tropenkoller' and 'philippinitis. ${ }^{4}$ Even non-pathological responses to the colonial situation were cast in distinctly epidemiological terms: With rumours and the unintelligible 'jungle-drums' as their source, anti-colonial conspiracies and insurgencies were seen to be contagious and could spread amongst the local population like an epidemic. ${ }^{5}$ Colonial identities and relationships were furthermore galvanized during such moments of crisis, and colonial mastery and masculinity was forged, or destroyed, in the face of perceived threats, while white women nobly defended their virtue or succumbed to hysteria. ${ }^{6}$

The emphasis on the perceived vulnerability of the colonial condition, as well as the political instability of the colonial state, obviously runs the risk of overstating the argument-large swathes of the world were after all subjugated and occupied by Western imperial powers leaving a lasting legacy the ramifications of which are still felt today. ${ }^{7}$ Accordingly, the real challenge facing the historian is to navigate the dichotomy between what Michael G. Vann has described as the contradiction of "white power and white vulnerability." 8 How do we take seriously colonizers' sense of weakness when colonialism was defined by coercion and when crises within the European empires were so often followed by brutal suppression and the violent reassertion of colonial authority?

This essay revisits the events surrounding one of the most emblematic instances of colonial violence: The Amritsar Massacre of 1919, when colonial troops under General Dyer fired on a crowd of Indians killing hundreds and wounding more than a thousand. ${ }^{9}$ Deliberately sidestepping the "big event," and ignoring the "important" historical figures, the following pages focus instead on the experience of a single, relatively unknown, individual, Mrs. Melicent Wathen, as recounted in her diary. ${ }^{10}$ Melicent, or Mel as she was known, was the wife of Gerard Wathen, principal of the Khalsa College in Amritsar, the supposed model for E. M. Forster's character of Henry Fielding in $A$ Passage to India. ${ }^{11}$ The diary reflects the experience of the British Raj in peril and its denizens in headlong flight - a notion repeatedly invoked by General Dyer and his supporters at the time, but which historians have dismissed as hyperbolic and calculated attempts to legitimise colonial suppression. ${ }^{12}$ Although the situation in Punjab was undoubtedly serious, the British in India were not about to be overrun in 1919, and it is this basic incongruity that makes the British response to anti-colonial riots appear so blatantly disproportionate and callously brutal. ${ }^{13}$ From the distance of a century, it is virtually impossible to reconcile the violent spectacle of the Amritsar Massacre with claims of British victimhood. It is nevertheless precisely when we make allowance for diverse perspectives, however implausible, that we can 
appreciate the complexities of the past, and the multiplicity of past experiences. Melicent's diary offers a glimpse of a well-known story told anew: Where most histories of the Amritsar Massacre emphasize British brutality and Indian suffering, her experience was characterized by fear and the uncertainty of what became a headlong flight from empire.

\section{Amritsar 1919: The Diary of Melicent Wathen}

Until 1919, the lives of the Wathens could have been ripped from the pages of Kipling: The hot seasons were spent at the picturesque hill station of Gulmarg in Kashmir and back at the Khalsa College in Amritsar acquaintances kept stopping by for visits, weddings of young friends had to be arranged, and polo horses submitted for the annual show at Lahore. ${ }^{14}$ When the Wathens returned from the New Year holiday in early 1919, however, Gerard found for the first time that the Indian students at the Khalsa College were preoccupied by politics. In light of the fact that the Indian National Congress was to hold its next annual meeting at Amritsar, he went out of his way to talk to his students and "explain" the recent colonial legislation, especially the much-maligned Rowlatt Acts which were "the present cry taken up by the Seditionists." ${ }^{15}$ Engaging with the students in this manner turned out to have been well worth the effort, as Melicent later wrote, since Gerard's work "was most doubly repaid when the trouble came." ${ }^{16}$ Hartals, or strikes, called by Gandhi's burgeoning Satyagraha movement in protest against the Rowlatt Acts, soon became a recurrent feature throughout Punjab, alongside misinformation about the way the laws would interfere with peoples' public and private lives. "These lies were specially spread amongst the lower classes such as the tonga wallahs and sweepers and fruit sellers," according to Melicent, and "by the beginning of April we realized things were nasty." ${ }^{17}$ Even so, Gerard took a week off to go shooting, and the family went together to enjoy the festivities at the Mela Hola Mohalla festival at the nearby Sikh shrine at Tarn Taran. A missionary couple they met there nevertheless reminded the Wathens that all was not well as they "spoke gravely and foretold a bad Sikh rising in the near future. $" 18$

Back in Amritsar things now began to happen very quickly: when Melicent took an acquaintance to see the Golden Temple on Saturday, 5 April, she found the number of locals gathered, with no obvious purpose, to be highly disconcerting and hurried home towards the British lines: "for the first time I had an instinctive feeling of relief as I crossed the railway bridge out of the city." ${ }^{19}$ The very next day there was a political meeting in the "native" part of town and "a nasty crowd collected." ${ }^{20}$ The Anglo-Indian community continued to go about their ordinary routine, yet the pretence of normalcy became increasingly difficult to maintain: "We went to church but the road was guarded and the soldiers wore ball cartridges. ${ }^{21}$ After that no Englishman could get a tonga - the shops refused to serve us - a sais was beaten who had been sent to fetch a tonga. There was no doubt that clouds were gathering-I refused to let the nurses go to the City on Tuesday." 22 On the following Wednesday, 9 April, 
Mr. Jarman, Municipal Engineer, lunched with the Wathens and told them that "a plot had been discovered to murder all Europeans on $16^{\text {th }}$ when Ghandi was expected." Moreover, the local nationalist leaders, Doctors S. Kithclew and Satyapal, were making "most inflammatory speeches and things were in a very bad state." ${ }^{23}$ This alarming news convinced Melicent that she needed to leave with her children as soon as possible. The annual trip to the hills, to escape the heat of the summer-months, had been scheduled for 25 April, but she now wired for a car for the thirteenth instead. ${ }^{24}$ Although none of the students at the Khalsa College had so far observed the hartals, ${ }^{25}$ which was considered "a great triumph" for Gerard, he was also hearing "serious rumours" through his teachers, and Melicent and he decided both to visit Commissioner Miles Irving in person. ${ }^{26}$ The commissioner was not at home and they were instead received by his wife who, to Melicent's dismay, "seemed not to have grasped the situation at all." If the Wathens had expected their worries to be put at ease, they were sorely disappointed and the commissioner's wife simply "laughed at the people who were nervous, said someone had thought arrangements ought to be made for women and children to go to the Fort if anything occurred, but nothing had been done and she didn't think they had remembered the people in the Khalsa College at all!" ${ }^{27}$ Melicent and Gerard left the commissioner's house "thoroughly dissatisfied about things." 28

That night Melicent and Gerard dined with several other couples, including the Becketts, who had just come back from Lahore where they witnessed the military and police firing on the crowds protesting the Rowlatt Acts. "But though it subsided then it was by no means over, Melicent lamented, "and yet this had not opened people's eyes. ${ }^{" 29}$ Melicent tried to get her dinner guests to come to their senses but, like Mrs. Irving, they dismissed the seriousness of the situation: "They laughed and Scott said it was ridiculous to be nervous with all our machine guns and aeroplanes. Poor man, he was dead within 15 hours — brutally murdered." ${ }^{30}$ Melicent resolved to leave with the children at the earliest possible date which was two days later, Friday the eleventh.

10 April, Thursday. The day began like any other day and servants sent to the bazaar to buy flour said that "all was quiet." ${ }^{31}$ Unbeknownst to the Wathens, however, the British authorities had decided to forestall any unrest and secretly arrested and deported the two nationalist leaders, Kitchlew and Satyapal, around 10:00 that morning. Melicent only found out what had occurred much later. Precautions were only considered after the arrests, when it was too late to do much, and a small military contingent of the Indian Defence Force (I.D.F.)-Melicent described them as "feeble and untrustworthy" - was placed at the disposal of the civil authorities at the Ram Bagh Gardens. ${ }^{32}$ Half a dozen mounted gunners were meanwhile posted at the railway bridge to guard the main road leading from the Indian city to the British lines. At 10:30, Commissioner Irving and Assistant Commissioner Beckett made a tour of the city, and while the former found "all satisfactory," the latter did not. ${ }^{33}$ Beckett was apparently "so unsatisfied" that he rode back to the bridge at 11:30 and now encountered "a furious mob pouring out, headed by pleaders and 
shouting for Kitchlew and Satyapal. ${ }^{34}$ Beckett tried to stop the crowd and promised to tell them where the two nationalist leaders were if they would retire to the gates of the city, but to no avail. He was pushed back over the bridge, towards the British lines, as the crowd made for the court house. At the foot of the bridge, Beckett found four mounted gunners posted whom he ordered to push the crowd back, but on no account to fire on them; he then rode off to get hold of his superior, Commissioner Irving. When Beckett later returned to the bridge, the crowd had been pushed back to the other side, but Extra Assistant Commissioner F. A. Connor informed him that he had been ordered with a handful of mounted troops to disperse the crowd: "This he had tried to do by firing on them-with the result that they went mad and he had to retire leaving the mob looting the National Bank and murdering every English man they could find and wrecked the telegraph and telephone office." 35

At the Khalsa College, the Wathens were slowly realizing that all was not well: "All that morning we knew things were unquiet, but how bad we did not guess till we were at lunch when Beckett galloped up looking very wild, his horse covered with foam and blood, saying the crowd was in the station and coming to the civil lines." ${ }^{36}$ Melicent had in fact been prepared for something like this all morning, "as I felt things were bad." ${ }^{37}$ First she dressed the children in comfortable cloths and prepared three small rolls of bedding that could easily be carried along with some food; then she put on her khaki riding trousers. And then the wait began, Melicent expected "to have to fly to the Professor's quarters or some village at any moment. It was not pleasant." 38 As the Wathens were walking around the College grounds, they met Mr. Kitchen, Commissioner in Lahore, who was passing in a car along with the deputy inspector of police. Gerard got in the car and they all went to see Irving, leaving Melicent behind at the college waiting for her husband: "It seemed hours till he came back. I don't know that I even expected him back, everything seemed all on end." ${ }^{39}$ Finally, at 3:00 in the afternoon, Gerard returned, "looking ghastly," with news of what had occurred that day: "Stewart, Scott, Thompson and two others had been hideously murdered. All Banks wrecked, the station wrecked, the telegraph office, a church and various other buildings and that but for an unexpected company of Gurkhas who had just passed through we must have been wiped out. All communication was cut and the lines below and above the station pulled up!" 40

As the Wathens were trying to come to terms with the magnitude of the day's events, a group of the Indian students and teachers appeared and, not being sure of their intentions, Melicent expected the worst: "here's the end I thought!" Yet Melicent's worries turned out to be misplaced as the students and teachers "came to beg Gerard to let them guard us and the college through the night and not to send us to the Fort! It was," she asserted, "a triumphant moment. After that my spirits rose a little." ${ }^{41}$ Melicent and the children were nevertheless still going to leave and their luggage was sent ahead to the small station of Chheharta in readiness for their departure by train to Rawalpindi. At 5:30, Gerard and Melicent drove over to the 
house of the Ashfords, which was the assembly point for the European women and children being evacuated to the fort:

It was a tragic sight-never did I see horror so grimly written on any face except those
who had come from the trenches. ${ }^{42}$ There were women and children all herded
together, several not knowing if their husbands were dead or alive. Some knew within
the hour that they were dead. Others were not relieved of their suspension till after
midnight. I uttered a heartfelt prayer of thankfulness as I drove home to my own
house to sleep. There were over 400 people in the Fort with no provisions but bully
beef and biscuits and only four bathrooms and three rooms. The dust and glare and
heat were ghastly-and several people and children went in ill. So much for the
forethought of our D.C. Miles Irving and yet he must have known.

That night the Wathens slept safely in the garden as usual, and Melicent even forgave the students who asked for new hockey balls so that they could play in the moonlight, although they ruined the flowers beds. Only later did they learn of the extent of the violence and destruction of the riots that day:

After the mob had gone mad, they attacked National Bank, beat Mr. Stewart with lathis and then pouring oil on him when he was half unconscious burnt him. They did the same to Mr. Scott-first piling the furniture on the top of him. Nothing was left of the Bank, it was gutted - they then went on to the Alliance Bank. Mr. Thomson defended himself and then ran upstairs and hid, but they found him, dragged him and threw him out of the window, poured oil on him while he was still alive and burnt him. They then burnt the R.C. Church, hunted and beat nearly to death a missionary, Miss Sherwood, saying she was English and must die. ... It was just as [the rioters] were marching to the Civil lines that the Gurkhas turned up, were detrained - fired on the mob and drove it back into the City and held it. At $7 \mathrm{pm}$ an aeroplane at last arrived from Lahore. At midnight the Londons came from Jullundur. At 2am those British troops and an armoured train arrived from Lahore. Only then may we have been said to be in some safety. ${ }^{44}$

11 April, Friday. At 7:00 a.m., when Gerard heard that troops would be entering the city and that they would open fire on everyone they encountered, he dashed off to the train station where the detachment was being prepared. A meeting of the local authorities was already under way and, as he later told Melicent, he spent an hour trying to dissuade them, arguing "that it was political madness to do such a thing now without warning. Yesterday when the murdering was in swing would have been a different matter." He finally managed to convince Major MacDonald (who had only just arrived from Lahore) and eventually the rest of the committee, and it was agreed that the crowds should be given till 2:00 p.m. to bury those killed the day before and then disperse. ${ }^{45}$ Gerard would send some of his students and a local maulvi [imam] to warn people within the city: "At 2 [p.m.] aeroplanes were to ascend and if the crowds still persisted bombs were to be dropped." 46

Meanwhile, Melicent and Mary, an acquaintance who was staying with them, were trying to finish the packing. The luggage that had been sent ahead was reported to be safe, although the servants had been bullied by the crowds who had apparently "looted the rest of the station." ${ }^{, 7}$ Gerard sent some of the students to watch over the 
luggage until the train they hoped to catch later that evening would pass through. "Our feelings were intense all that morning," Melicent noted, and she sought to distract herself with a novel:

I read the Secret City by Walpole feverishly in between whiles - the more lurid situation about the riots in Petrograd being peculiarly in keeping and somewhat harassing to one's nerves during those trying hours. ${ }^{48}$... No news from the city. Mary and I managed to pack away all my favourite things that morning - afterwards as I lay for a few minutes on the sofa, nerves stretched to breaking point, she gave me a whiskey and soda and I began to understand how people took to drink. ${ }^{49}$

The day passed, and the deadline for the dispersal of the crowd approached:

As the time drew on and 2 o'clock came nearer tension was intense. At last the hour struck - we heard the planes go up. Would they fire? Had the crowds dispersed? One, two, three minutes passed-Mary and I went onto the drive, breathless to listen. Gerard came up. Then the old maulvi appeared. He had been to the mosques. At the one by the Hall gate he had had some trouble to get a hearing, but he did so at last, they had listened to him gone to their homes. ... Still the planes hovered round, but no bomb was dropped. Gerard had saved the city and saved the government from endless political difficulties in the future. ${ }^{50}$

The Wathens walked around the grounds of the College and finally at 4:00 p.m. it was time for their departure and they all left-Melicent and the children packed into a tonga and Gerard riding alongside on his bicycle. They soon reached the train station two miles away, and with that a greater sense of safety: "At the station the relief of finding oneself guarded by plenty of troops was immense. British and Gurkhas, fully armed guarded every inch of the place, in a siding stood the armoured train, machine guns ready-overhead droned the two aeroplanes. At the relief after the last four days no-one can imagine." 51 Melicent described in great detail her and her husband's final hours together while waiting for the train that was to take her and the children to the safety of the hills - Gerard would travel with them only as far as Lahore:

We got some tea with great difficulty—not a soul was on the platform except the D.C. and Commissioner and these soldiers - everything was hushed and expectant. I couldn't help a sickening feeling at the thought of leaving Gerard and the journey before us, but I also felt the journey must be got through at all costs. The train was nearly four hours late, but she came in at last. ... At Lahore it was a grim spectacle - pickets of Sikhs up and down the platform, talk of strikes all down the line, processions, rioting, meetings in Lahore, grave looking soldiers eating hurried meals in the refreshment room, ourselves the only civilians. Gerard took me in for a last meal. He was dressed in khaki with his collar open and like every other man looked as though he had neither sleep or rest for days, like all these men he wore the tense look, the look of constant expectation - of what? Of what no-one could tell. He said "We may never meet again — things are as bad as they have even been in our history - the whole country is ablaze - We don't yet know what we are in for." And with almost these words, and very much these feelings, we parted. He standing there on that hot platform with its lurid half-light in which soldiers stood and sat in knots, they showed all that is best in our race and so we passed out of the station, only one thing certain, that we were all in greater danger at that moment than ever in our lives, or that I hope we may ever be again. ${ }^{52}$ 
Melicent and the children made it safely to Rawalpindi and then onwards to Gulmarg; it was at this hill-station in the beautiful hills of Kashmir that she wrote this part of her diary between 13 and 18 April 1919. Although she was to return to Amritsar in September of that year and continued her diary until her final departure from India the following December, only her experience in Amritsar up till 11 April will be discussed in what follows.

\section{An Intimate Account of Colonial Anxieties}

Melicent Wathen's diary provides a unique vantage point that allows for a radically different understanding of colonial fear and anxieties during the crisis of April 1919. Crucially, hers is a story of Amritsar in April 1919 without the massacre - and without General Dyer. Melicent and the children fled Amritsar in the evening of 11 April, mere hours before Dyer arrived and she only heard of the massacre through a letter from her husband a week later. Where most accounts simply start from the moment Dyer entered the stage, with but a brief reference to the preceding riots, Melicent's experience begins months before and ends the very moment that 'history' commences. Instead of the historically overdetermined narrative of the events leading up to the massacre at Jallianwala Bagh, we thus have a fragment of the past told as events were unfolding; and it is this very 'incompleteness' that makes Melicent's experience so remarkable. The Italian historian Giovanni Levi's description of microhistory seems pertinent in this regard: "Phenomena previously considered to be sufficiently described and understood assume completely new meanings by altering the scale of observation." 53 In Melicent's diary, the scale of observation is certainly altered and, unlike most other accounts, hers is not framed by the subsequent Hunter Committee inquiry, nor by the heated debates amongst politicians and in the press, in India and in Britain, which sought to either condemn or condone British violence. This is not to say that the diary presents a more "authentic" narrative, merely that it is unburdened by the hindsight so characteristic of most of the contemporary accounts. In comparison, the article written by Mrs. Beckett, the wife of the magistrate, and published anonymously in Blackwood's Magazine in 1920 had as its explicit aim to show how Dyer's actions saved the lives of the European women and children at Amritsar. ${ }^{54}$

Melicent wrote her diaries intermittently throughout the decade up till 1919; she documented the most significant events in her life, interspersed by the quotidian, and then put down the diary only to take it up much later. The diaries are full of memorabilia taped to the pages, including locks of her children's hair or the colourful feathers of birds, but also contain numerous small water-colour sketches of ruins, palm trees and sunsets of the type beloved by so many amateur artists of the Raj. ${ }^{55}$ Although the diaries in places have a certain literary quality, Melicent did not seem to be writing for anyone else; allusions to her misgivings about Gerard's decisions, or her explicit criticism of Commissioner Irving, for instance, suggest that it was not intended for publication or a wider readership, even within her family. The diaries 
were only made public long after both Gerard and Melicent had passed away. ${ }^{56}$ The entries relating to Amritsar in 1919 constitute one discreet "chapter" and although they relate events as they are unfolding, they also reflect an attempt at making sense of a traumatic experience and imbue extremely confusing events with a sense of coherence. It was from the safety of the hills in mid-April that Melicent looked back over the preceding months and decided to describe the sequence of events that brought her and the children there.

The overriding mood, and indeed the leitmotif of Melicent's account, is that of an increasing sense of vulnerability fuelled by uncertainty and the fact that the Wathens were very much at the margins of the European community at Amritsar. Gerard apparently loathed "Anglo-India," as the Forster-circle described the pukka sahibs and memsahibs, and earlier entries in Melicent's diary suggest that she only frequented the European club to be polite. ${ }^{57}$ Melicent's description of the women and children seeking refuge in the fort at Amritsar, and the primitive conditions with which they had to make do, is particularly revealing in this respect. Where the account of her compatriots, such as that of Mrs. Beckett, includes prayers for everyone's safety, Melicent is simply grateful for not having to endure the discomfort of the fort along with everybody else. This feeling of exclusion, in part self-chosen, was further exacerbated by the manner in which the Wathens' concerns were dealt with, or rather ignored, by the authorities in the days leading up to the riots. The Wathens had apparently been forgotten when the evacuation plans were made and their disillusionment with the ability of the local authorities to protect them had a profound impact on Melicent's experience of the unrest. ${ }^{58}$ To make matters worse, the Wathens began to fear even their own servants and friends amongst the Indiansan escalation of the sense of unease Melicent had previously expressed when visiting the 'native' city. ${ }^{59}$ During the crisis at Amritsar, the Wathens found that they could trust neither the locals, nor the colonial administration, and the feeling of isolation and vulnerability was thus near complete. ${ }^{60}$

As the principal of a Sikh school, and one with an openly liberal leaning at that, Gerard was not part of the official colonial establishment and Melicent was thus doubly disempowered - both as an outsider and as a woman. Most of her diary is spent worrying about Gerard, as Melicent was largely confined to the bungalow, waiting for news of her husband and for things to happen to her and her family. Interestingly, Malcolm Darling, who was part of E. M. Forster's clique in India, knew the Wathens at Lahore before they moved to Amritsar and had severe misgivings about the nature of Gerard and Melicent's relationship and the manner in which he seemed to completely neglect her in favour of his work. Allegedly, Melicent stood in the shadow of, and was utterly dedicated to, her absent-minded husband. ${ }^{61}$ While other accounts highlight the courage and solidarity amongst the women seeking refuge in the fort, so reminiscent of the siege-narratives of the 'Mutiny,' Melicent only has eyes for her husband's safety and it is Gerard and the British soldiers who "prove all the is best in our race." When going over her experiences in the diary, however, Melicent retrospectively ordered this confusion and uncertainty, 
and the entire narrative is structured in a strictly teleological fashion, constantly prefiguring what would later happen. The diary, as a result, takes the shape of a vindication of Melicent's fears - her vague sense that something bad was about to happen, which was repeatedly dismissed by her fellow Anglo-Indians, turned out to be only too prescient. ${ }^{62}$ While it may have been Gerard's actions that prevented the escalation of the violence at Amritsar, it was thanks to Melicent's wherewithal that she and the children got away in time. Subtle as it may have been, some agency is thus restored to the worrying memsahib, yet this hardly constitutes a challenge to the established narrative of gender roles during colonial crises: In Melicent's telling, the men are still the main actors who prove their chivalry through vigorous action to protect the passive and helpless women. ${ }^{63}$

Exactly what Melicent and the children were fleeing from is, however, never quite clear and the diary does not provide anything approaching a meaningful description of Indian nationalism or Gandhi's burgeoning Satyagraha movement. With no real comprehension of the nature of anticolonial sentiments in India in 1919, Melicent responds to a hazy and racialized vision of "nasty crowds" guided by faceless "seditionists" - threatening precisely because it is poorly understood. Melicent's emotional experience, though, was not merely a symptom of the colonial malaise that seemingly afflicted most of her fictional co-colonisers populating the works of the likes of Orwell and Maugham. ${ }^{64}$ In his article "Not at Home in Empire," Ranajit Guha differentiates between fear and anxiety in the colonial context: the former referring to the concrete threat to the colonial state posed by, for instance, indigenous conspiracies and rebellions, and the latter signifying the alienation and pervasive unease experienced by some colonisers, isolated and outnumbered, in the far-flung corners of empire. ${ }^{65}$ Fear had a specific cause, which could be acted upon, whereas anxiety by its very nature defied understanding, and it was this that produced an uncanny effect. ${ }^{66}$ Guha's absolute distinction is nevertheless misleading and ultimately underwrites the connotation of fear and anxiety with, respectively, rationality and irrationality. ${ }^{67}$ Fear and anxiety cannot be reduced simply to concepts that have to be historicized according to the norms of a given age, society or class. Emotions form but a part of the experience of the past, and if the aim is to provide a "thick description" and comprehensive examination of particular events or structural dynamics, they ought not to be reified as epiphenomena. ${ }^{68}$

Like conspiracy theories, and the mind-set described in Richard Hofstadter's "The Paranoid Style," colonial anxieties constituted a mode of political interpretation. To merely dismiss them as irrational is to miss the point ${ }^{69}$ More than just an emotional response, fear is a way of seeing the world, and fear profoundly shaped the manner in which Melicent experienced the events unfolding at Amritsar in April 1919. The fear of a Sikh uprising, or the absurd story that the arrival of Gandhi would herald the wholesale murder of Europeans, are glaring examples of the inability to separate political realities from the bogeyman of native conspiracies - what I have elsewhere referred to as the 'Mutiny'-motif. ${ }^{70}$ Concrete fears and vague anxieties were thus mutually reinforcing, and during colonial crises, knowledge and rumour, panic and 
vigilance, became virtually indistinguishable. What Melicent's teleological account does not reveal, however, is the fact that British panic and preemptive action sparked the riots that eventually led to the Amritsar Massacre; what she presented as warranted vigilance was really a form of self-fulfilling paranoia. However bizarre, the notion of British victimhood at Amritsar was no mere conceit and colonial anxieties were constitutive of colonial violence. Perhaps, after all, General Dyer was not being so disingenuous when he claimed that his actions were motivated by fear-it was unfortunately a fear caused by a paranoid colonial imaginary rather than the actual situation confronting him. ${ }^{71}$

If we are to engage comprehensively with the lived experience of empire, the forms and functions of colonial fears and anxieties must be acknowledged - not because colonial panics were founded on facts, which they were not, but because they played such a crucial role in shaping colonial policies and framing the relationship between rulers and ruled. Melicent's diary offers an intimate account of colonial crisis - a perspective beyond the overtly political language, reflected in the quote by Dyer cited at the beginning of this article, and beyond the two-dimensional caricature of AngloIndians so often mediated exclusively through fiction, as exemplified by Orwell.

\section{Bibliography}

\section{Primary sources}

Depositions: O'Dwyer v. Nair. J17/634, National Archive, Kew.

Diary of Melicent Wathen, India, 1914-1920 (kept by Wathen family).

Disorders Inquiry (Hunter) Committee 1919-20: Evidence, vol. 3: Amritsar. (Calcutta: 1920). Indian National Congress Subcommittee. Report of the Commissioners Appointed by the Punjab Sub-committee of the Indian National Congress, 2 vols. Bombay: Karnatak Press, 1920.

National Archives of India (NAI), Home Department, Political A, Proceedings, October 1919, nos. 421-24.

Omissi, D. "The Mills and Boon Memsahibs: Women's Romantic Indian Fiction, 1877-1947." PhD diss., Lancaster University, 1995.

Sedition Committee, 1918 (Report). Calcutta: Superintendent of Government Printing, India, 1918.

\section{Secondary sources}

Anderson, W. Colonial Pathologies: American Tropical Medicine, Race, and Hygiene in the Philippines. Durham: Duke University Press, 2006.

Anonymous (Mrs. Beckett). "Amritsar. By an Englishwoman.” Blackwood's Magazine (April 1920): 441-46.

Arnold, D. Toxic Histories: Poison and Pollution in Modern India. Cambridge: Cambridge University Press, 2016.

Banivanua-Mar, Tracey and Penelope Edmonds, eds. Making Settler Colonial Space: Perspectives on Race, Place and Identity. Houndmills: Palgrave Macmillan, 2010.

Bayly, C. A. Empire and Information: Intelligence Gathering and Social Communication in India, 1780-1870. Cambridge: Cambridge University Press, 1996.

Beckett, Elisabeth. The British Raj, vol. 2: Decay. Edited by John Wrake. N.p.: CreateSpace Independent Publishing Platform, 2011. 
Bhabha, Homi K. The Location of Culture: Critical Theory and the Postcolonial Perspective. Oxford: Oxford University Press, 1991.

Blunt, Alison. "Embodying War: British Women and Domestic Defilement in the Indian 'Mutiny', 1857-8." Journal of Historical Geography 263 (2000): 403-28.

Bourke, Joanna. "Fear and Anxiety: Writing about Emotion in Modern History." History Workshop Journal 55 (2003): 111-33.

- Fear: A Cultural History. London: Virago, 2005.

Brendon, Vyvyen. Children of the Raj. London: Weidenfeld \& Nicolson, 2005.

Brownfoot, J. "Memsahibs in Colonial Malaya: A Study of European Wives in a British Colony and Protectorate, 1900-1940." In The Incorporated Wife, edited by Hillary Callan and Shirley Ardener, 186-210. Croom Helm, London, 1984.

Callaway, Helen, Gender, Culture and Empire: European Women in Colonial Nigeria. Basingstoke: Macmillan, 1987.

Choudhury, D. K. Lahiri. "Sinews of Panic and the Nerves of Empire: The Imagined State's Entanglement with Information Panic, India c. 1880-1912." Modern Asian Studies 38:4 (2004): 965-1002.

Cohen, Paul A. History in Three Keys: The Boxers as Event, Experience, and Myth. New York: Columbia University Press, 1997.

Collett, Nigel. The Butcher of Amritsar: General Reginald Dyer. London: Hambledon Continuum, 2005.

Condos, Mark. "Fanaticism' and the Politics of Resistance along the North-West Frontier of British India." Comparative Studies in Society and History 58:3 (2016): 1-29.

Dalrymple, William. The Last Mughal: The Fall of a Dynasty, Delhi, 1857. London: Bloomsbury, 2006.

Draper, Alfred. The Massacre that Ended the Raj. London: Cassell, 1981.

Dewey, Clive. Anglo-Indian Attitudes: The Mind of the Indian Civil Service. London: Hambledon, 1993.

Doran, Christine. "Gender Matters in the Singapore Mutiny." Sojourn: Journal of Social Issues in Southeast Asia 17:1 (2002): 76-93.

Ernst, Waltraud. Mad Tales from the Raj: The European Insane in British India, 1800-1858. London: Routledge, 1991.

Fischer-Tiné, Harald, ed. Anxieties, Fear and Panic in Colonial Settings: Empires on the Verge of a Nervous Breakdown. Cham, Switzerland: Palgrave Macmillan, 2016.

Forster, E. M. A Passage to India. London: Edward Arnold, 1924.

Gartrell, Beverley. "Colonial Wives: Villains or Victims." In The Incorporated Wife, edited by Hillary Callan and Shirley Ardener, 165-86. Croom Helm, London, 1984.

Ginzburg, Carlo. "Microhistory: Two or Three Things That I Know About It." Translated by John Tedeschi and Anne C. Tedeschi. Critical Inquiry 20:1 (1993): 10-35.

Gilroy, Paul. After Empire: Melancholia or Convivial Culture? London: Routledge, 2004.

Guha, Ranajit. "Not at Home in Empire." Critical Inquiry 23:3 (1997): 482-93.

_ . "The Prose of Counter-Insurgency." In Subaltern Studies II, 1-42. Delhi, 1983. Reprinted in Ranajit Guha and G. C. Spivak, eds. Selected Subaltern Studies, 45-88. New York, 1988.

Hofstadter, Richard. "The Paranoid Style in American Politics." Harper's Magazine (Nov. 1964): 77-86.

Houlbrook, Matt. "A Pin to See the Peep Show: Culture, Fiction and Selfhood in Edith Thompson's Letters, 1921-1922.” Past \& Present 207:1 (2010): 215-49.

Jackson, Will. Madness and Marginality: The Lives of Kenya's White Insane. Manchester: Manchester University Press, 2013.

Jackson, Will and Emily Manktelow, eds. Subverting Empire: Deviance and Disorder in the British World. Basingstoke: Palgrave Macmillan, 2015. 
Kaye, John W. and George Malleson. History of the Indian Mutiny. London: W. H. Allen, $1888-89$.

Kaye, M. M. Kaye and David Larkin. The Far Pavilions Picture Book. Harmondsworth: Penguin Books, 1979.

Kennedy, Dane. The Magic Mountains: Hill Stations and the British Raj. Delhi: Oxford University Press, 1996.

Kuhn, Philip A. Soulstealers: The Chinese Sorcery Scare of 1768. Cambridge: Harvard University Press, 1990.

Kumar, R. ed. Essays on Gandhian Politics: The Rowlatt Satyagraha of 1919. Oxford: Clarendon Press, 1971.

Laffan, Michael and Max Weiss, Max, eds. Facing Fear: The History of an Emotion in Global Perspective. Princeton: Princeton University Press, 2012.

Lal, Vinay. "The Incident of the Crawling Lane: Women in the Punjab Disturbances of 1919." Genders 16 (Spring, 1993): 35-60.

Levi, Giovanni. "On Microhistory." In New Perspectives on Historical Writing, edited by Peter Burke, 97-119. Cambridge: Polity Press, 1995.

Levine, Philippa, ed. Gender and Empire. Oxford: Oxford University Press, 2004.

MacMillan, Margaret. Women of the Raj. New York: Thames and Hudson, 1988.

Mahone, Sloan. "The Psychology of Rebellion: Colonial Medical Responses to Dissent in British East Africa." The Journal of African History 47:2 (2006): 241-258.

Masters, John. Nightrunners of Bengal. London: M. Joseph, 1951.

- The Deceivers. London: M. Joseph, 1952.

Maugham, W. Somerset. Eastern Tales. London: Mandarin, 1993.

- More Eastern Tales. London: Mandarin, 1998.

McCulloch, Jock. Black Peril, White Virtue: Sexual Crime in Southern Rhodesia, 1902-1935. Bloomington: Indiana University Press, 2000.

Morrison, Alexander. "Sufism, Panislamism \& Information Panic: Nil Sergeevich Lykoshin and the aftermath of the Andijan Uprising." Past \& Present 214 (Feb. 2012): 255-304.

Orwell, George. Burmese Days. 1934. Reprint London: Penguin Books, 1986.

—. "Shooting an Elephant." New Writing 2 (1936).

Padamsee, Alex. Representations of Indian Muslims in British Colonial Discourse. Basingstoke: Palgrave Macmillan, 2005.

Pape, John. "Black and White: The 'Perils of Sex' in Colonial Zimbabwe." Journal of Southern African Studies 16:4 (1990): 699-720.

Parry, Benita. Delusions and Discoveries: Studies on India in the British Imagination, 1880-1930. Berkeley: University of California Press, 1972.

Paxton, Nancy L. Writing Under the Raj: Gender, Race, and Rape in the British Colonial Imagination, 1830-1947. New Brunswick: Rutgers University Press, 1999.

Peckham, Robert. Empires of Panic: Epidemics and Colonial Anxieties. Hong Kong: Hong Kong University Press, 2015.

Pincince, John. "De-centering Carl Schmitt: The Colonial State of Exception and the Criminalization of the Political in British India, 1905-1920." Politica Común (2014). DOI: www.dx.doi.org/10.3998/p c. 12322227.0005 .006

Plamper, Jan, and Lazier, Benjamin, eds. Fear Across the Disciplines. Pittsburgh: University of Pittsburgh Press, 2012.

Popplewell, Richard James. Intelligence and Imperial Defence: British Intelligence and the Defence of the Indian Empire, 1904-24. London: Frank Cass, 1995.

Reinkowski, Maurus, and Gregor Thum, eds. Helpless Imperialists: Imperial Failure, Fear and Radicalization. Göttingen: Vandenhoeck \& Ruprecht, 2013. 
Roque, Ricardo. "The Razor's Edge: Portuguese Imperial Vulnerability in Colonial Moxico, Angola." The International Journal of African Historical Studies. Special Issue: Colonial Encounters between Africa and Portugal 36:1 (2003): 105-124.

Rosenberg, Emily S. ed. A World Connecting, 1870-1945. Cambridge: Harvard University Press, 2012.

Sayer, Derek. "British Reactions to the Amritsar Massacre 1919-1920." Past \& Present 131:1 (1991): 130-164.

Sharpe, Jenny. Allegories of Empire: The Figure of Woman in the Colonial Text. Minneapolis: University of Minnesota Press, 1993.

Siddiqi, Yumna. Anxieties of Empire and the Fiction of Intrigue. New York: Columbia University Press, 2008.

Stoler, Ann Laura. "'In Cold Blood': Hierarchies of Credibility and the Politics of Colonial Narratives.” Representations 37 (Winter, 1992): 151-189.

Taylor, Sherman. State Violence and Punishment in India, 1919-1956. London: Routledge, 2010.

Tickell, Alex. Terrorism and Insurgency in Indian-English literature: Writing Violence and Empire. London: Routledge, 2012.

Trevelyan, Raleigh. The Golden Oriole. London: Secker and Warburg, 1987.

Van Dijk, C. "Colonial Fears, 1890-1918: Pan-Islamism and the Germano-Indian Plot." In Transcending Borders: Arabs, Politics, Trade and Islam in Southeast Asia, edited by H. de Jonge and N. Kaptein, 53-89. Leiden: KITLV Press, 2002.

Vann, Michael G. "Fear and Loathing in French Hanoi: Colonial White Images and Imaginings of 'Native' Violence." In The French Colonial Mind. Vol. 2, Violence, Military Encounters, and Colonialism, edited by Martin Thomas, 52-76. Lincoln: University of Nebraska Press, 2011.

Wagner, Kim A. "Calculated to Strike Terror: The Amritsar Massacre and the Spectacle of Colonial Violence.” Past \& Present 233:1 (2016): 185-225.

. The Great Fear of 1857: Rumours, Conspiracies and the Making of the Indian Uprising. Oxford: Peter Lang Oxford, 2010.

_. "Treading Upon Fires': The 'Mutiny'-Motif and Colonial Anxieties in British India." Past \& Present 218:1 (2013): 159-97.

Wathen, Mark. Banker, Soldier, Farmer, Priest: Personal Memories. Dunkirk: Barnwell Print, 2009.

White, Luise. Speaking with Vampires: Rumor and History in Colonial Africa. Berkeley: University of California Press, 2000.

Yang, Anand. "A Conversation of Rumours: The Language of Popular 'Mentalités' in Late Nineteenth-Century Colonial India." Journal of Social History 20:3 (Spring 1987): 485-505. Yeats-Brown, Francis. The Lives of a Bengal Lancer. New York: Viking Press, 1930.

\section{Notes}

* Kim A. Wagner teaches the history of colonial India and the British Empire at Queen Mary, University of London. His most recent book is The Skull of Alum Bheg: The Life and Death of a Rebel of 1857 (Hurst, 2017).

1 This article has benefited from discussions I have had with Will Jackson, Thomas Dickson, Rhodri Hayward, Mark Condos, and Harald Fischer-Tiné.
2 Some of the key works on the topic includes: Stoler, "In Cold Blood"; Bayly, Empire and Information; Roque, "The Razor's Edge"; Reinkowski and Thum, Helpless Imperialists; Morrison, "Sufism, Pan-Islamism and Information Panic"; Van Dijk, "Colonial Fears"; and Wagner, "Treading Upon Fires." For a discussion of colonial anxieties in literature, see Bhabha, The Location of 
Culture; Guha, "Not at Home in Empire"; Siddiqi, Anxieties of Empire; and Tickell, Terrorism, Insurgency and Indian-English Literature. The most recent addition to the field, FischerTiné, Anxieties, Fear and Panic in Colonial Settings, was unfortunately published too late for its contributions to be reflected in the current article.

3 See for instance Mahone, "The Psychology of Rebellion"; and Condos, "Fanaticism" and the Politics of Resistance."

4 Ernst, Mad Tales from the Raj; Anderson, Colonial Pathologies; Jackson, Madness and Marginality.

5 Choudhury, "Sinews of Panic"; Peckham, Empires of Panic; Arnold, Toxic Histories. For studies of rumours in an imperial and colonial context, see Yang, "A Conversation of Rumours"; Kuhn, Soulstealers; White, Speaking with Vampires; Cohen, History in Three Keys; and Wagner, The Great Fear of 1857.

6 Pape, "Black and White"; McCulloch, Black Peril, White Virtue; Jackson and Manktelow, Subverting Empire; Paxton, Writing Under the Raj; and Sharpe, Allegories of Empire.

7 Gilroy, After Empire.

8 Vann, "Fear and Loathing in French Hanoi," 52.

9 See Taylor, State Violence; and Wagner, "Calculated to Strike Terror."

10 Diary of Melicent Wathen, India, 1914 1920, 169-181 (henceforth referred to as MW Diary). I am grateful to Roderick Wathen for letting me work with the original diaries and for the hospitality of the Wathen family in Norwich.

11 Forster, A Passage to India; and Collett, The Butcher of Amritsar, 483. For accounts of colonial wives elsewhere, see Callaway, "Gender, Culture and Empire"; Brownfoot, "Memsahibs in Colonial Malaya"; and Gartrell, "Colonial Wives."

12 Sayer, "British Reactions to the Amritsar Massacre."
13 Indian rioters attacked and killed five Europeans at Amritsar on 10 April 1919. General Dyer ordered his troops to fire at Jallianwala Bagh three days later, resulting in at least 400 dead and upwards of a thousand wounded, and this was followed by an extended period of martial law and indiscriminate punishment across the region. The key collections of primary sources are Disorders Inquiry (Hunter), vol. 3; Indian National Congress Subcommittee, Report of the Commissioners, vols. 1-2; and O'Dwyer vs Nair.

14 MW Diary, 169.

15 MW Diary, 170. Countermanding the liberal reforms of the preceding decade, the so-called Rowlatt Acts effectively entailed the suspension of the rule of law to enable the British authorities effectively combat what they perceived as the major threat of revolutionary nationalism, the spread of Bolshevism, and to deal with the potential radicalization of demobilized Indian troops. See Sedition Committee, 1918; and Popplewell, Intelligence and Imperial Defence, 297-320.

16 MW Diary, 170. The teleological wording clearly indicates that this was written after the riots of 10 April 1919.

17 Ibid. No distinction is here made between the various, and at times incompatible, strands of Indian nationalism and the broader implication is evidently that anticolonial sentiments were not genuine, and certainly not politically legitimate. See Kumar, The Rowlatt Satyagraha.

18 MW Diary, 171. Ever since the Indian Uprising of 1857 , commonly referred to as the "Mutiny," the British feared that nationalist protests and local unrest might turn into a second "Mutiny"; see Wagner, The Great Fear of 1857, and idem, "Treading Upon Fires."

19 MW Diary, 171. As Antoinette Burton has recently pointed out, British concerns about local unrest at Amritsar revolved around the "racial ordering of space in colonial cities." Here, it is obvious that 
Melicent equates the Civil Lines with safety, whereas the "native" city is the site of sedition and hence the geographic location of fear; see Rosenberg, A World Connecting, 309. See also Mar and Edwards, Making Settler Colonial Space.

20 MW Diary, 171. The act of Indians mobilizing for political purposes was in and of itself seen as threatening, and it is likely that Melicent perceived the crowd to be "nasty" simply because it had gathered for such a meeting. The "prose of counter-insurgency," to use Ranajit Guha's concept, which implicitly criminalized the politics of indigenous movements, was not only a matter of misrepresentation, but also shaped how these movements were experienced and (mis)understood by colonisers. See Guha, "The Prose of Counter-Insurgency" and also Pincince, "De-centering Carl Schmitt."

21 During the outbreak of the uprising in 1857, British troops in some locations had been caught off guard and unarmed while they attended church services, and carrying loaded arms for church henceforth became one of the legacies of the "Mutiny"; see Wagner, The Great Fear of 1857. The reenactment of such precautionary measures constituted a tangible link between the past and the present and was as such constitutive of the manner in which the situation in 1919 was perceived.

22 MW Diary, 171. Melicent is here giving voice to an increasing sense of being isolated, if not actually besieged, and the 'native' city is quite explicitly identified as a dangerous place.

23 Ibid. No evidence was ever discovered of the existence of a conspiracy in 1919, let alone one involving Gandhi. The fear of indigenous conspiracies was nevertheless a recurrent theme in the repertoire of colonial nightmares, which in India drew on the much-popularized precedents of 'Thuggee' as well as the 'Mutiny,' see Wagner, The Great Fear, and Wagner, "Treading Upon Fires."
24 MW Diary, 171. During 1857, European women and children had also been sent to the hills for safety; see Kennedy, The Magic Mountains. Although Melicent never mentioned the "Mutiny" explicitly, it constituted an implicit backdrop to the Anglo-Indian experience of the unrest in 1919.

25 A hartal was a political strike resorted to by Indian nationalists.

26 MW Diary, 171-72.

27 MW Diary, 172. It would appear that the local authorities at Amritsar were deliberately putting on a show of confidence, as there is no hint of the complacency that so dismayed the Wathens in the panicked reports sent by Irving to his superiors at Lahore; see Disorders Inquiry (Hunter), vol. 6.3.

28 MW Diary, 172.

29 Ibid., 172.

30 Ibid., 172. Such teleological interjections in the narrative are obvious signs of the hindsight that shaped the actual writing of the diary.

31 Ibid.

32 Ibid., 173.

33 MW Diary, 173. There are several allusions in the primary records suggesting a level of tension, as well as confusion, over responsibility amongst the local authorities at Amritsar. These conflicts, however, were not subsequently brought to the attention of the public, see Disorders Inquiry (Hunter), vol. 3. Ann Laura Stoler's article, "In Cold Blood," provides a classic study of the tensions and fissures within the colonial state administration during such panics.

34 MW Diary, 173.

35 MW Diary, 174. It may be noted that there were varying accounts of the exact sequence of what occurred at the two bridges, see Disorders Inquiry (Hunter), vol. 3. What is not disputable, however, is the fact that the Indian crowd was seen to pose a threat to the entire European community by mere virtue of crossing the railway lines, and it was to prevent this invasion of the sanctity of "white" space that they were fired upon. 
36 MW Diary, 174.

37 Ibid.

38 Ibid. British families having to flee for their lives, and having to hide in jungles or Indian villages, was another trope central to the conventional 1857 narrative; see, for instance, Dalrymple, The Last Mughal.

39 MW Diary, 174.

40 Ibid., 175.

41 Ibid., 175.

42 The reference to the experience of the First World War, and its impact on the human psyche, is notable and shows the diary to be very much reflective of its time.

43 MW Diary, 175-76.

44 Ibid., 176-7. This description of the events is largely accurate.

45 Between twenty and thirty Indians were killed when the British troops on several occasions fired to drive the crowds back from the railway bridge and the train station during the turmoil of 10 April, see Disorders Inquiry (Hunter), vol. 3.

46 MW Diary, 177.

47 Ibid., 178.

48 For an excellent study of how women could live "through fiction" during the interwar period, see Houlbrook, A Pin to See the Peep Show.

49 MW Diary, 178.

50 Ibid., 178-9. The threat of bombing Amritsar from the air is not mentioned in the official records, nor is any involvement of Gerard Wathen, see Disorders Inquiry (Hunter), vol. 3. Although Melicent may have exaggerated her husband's role in preventing British retributive violence, it is unlikely that she made up the episode entirely. British airplanes did drop bombs and fire with machine guns on Indian crowds elsewhere in the Punjab during the unrest, see Disorders Inquiry (Hunter), vol. 5.

51 MW Diary, 179.

52 Ibid., 180-1. Strongly reminiscent of a scene from a Hollywood movie, Melicent's description of the farewell scene is self-consciously melodramatic and reveals something of the literary work at play within the diary.

53 Levi, "On Microhistory," 98. Carlo Ginzburg makes much the same argument in "Microhistory," 22.

54 Anonymous, "Amritsar"; and Beckett, The British Raj, vol. 2.

55 See Kaye and Larkin, The Far Pavilions Picture Book, for a good example of this particular genre. On women writing on British India, see, for instance Omissi, "The Mills and Boon Memsahibs"; and Parry, Delusions and Discoveries, 70-99.

56 According to the Wathen family, the author Alfred Draper was offered the use of the diary in preparation for his 1981 book The Massacre that Ended the Raj, but he did not ultimately do so. Brief excerpts from the diaries have subsequently been cited in a number of books, including Trevelyan, The Golden Oriole; Collett, The Butcher of Amritsar; and Brendon, Children of the Raj. Longer excerpts are reproduced in Wathen, Banker, Soldier, Farmer, Priest; and Beckett, The British Raj, vol. 2.

57 Trevelyan, 476.

58 It may be noted that the European Association at Amritsar later petitioned, albeit unsuccessfully, for a commission to investigate the failure of the British authorities to adequately protect them during the riots of 10 April 1919; see NAI, Home Department, Political A, Proceedings, October 1919, nos. 421-424.

59 Although this distrust turned out to be entirely unfounded, it is noticeable that every instance of Indian "loyalty" during the unrest is attributed by Melicent to Gerard's personal efforts and the account is thus framed as an implicit victory for liberal paternalism. When colonial authority was at its weakest, the local population could prove their loyalty, thereby testifying to the success of the civilizing mission, or, conversely, reveal their "true nature" as inherently irrational and bloodthirsty "savages," denoting its failure. 
60 See also Blunt, "Embodying War"; and Doran, "Gender Matters'; MacMillan, Women of the Raj; and Levine, Gender and Empire.

61 Dewey, Anglo-Indian Attitudes, 180-81.

62 The theme of the vigilant colonial protagonist, who knows the land and can correctly interpret the signs of impending unrest but whose warnings are consistently ignored by an ignorant and complacent administration, is, of course, a recurrent motif in Anglo-Indian fiction as embodied in, for instance, John Masters' novels about "Thuggee" and the "Mutiny," The Deceivers and Nightrunners of Bengal, respectively.

63 It is worth noticing that the sexual threat posed by Indian men is never mentioned or even alluded to in the diary; but see Forster A Passage to India, Lal, "The Incident of the Crawling Lane." It is unfortunately not possible to fully explore Melicent's depiction of race within the scope of the present article.

64 Orwell, Burmese Days, and Maugham, Eastern Tales and More Eastern Tales.
It may also be noted that Melicent never experienced an epiphany of the sort Orwell does in "Shooting an Elephant," but retained her staunch belief in the liberal imperial project. See Guha, "Not at Home in Empire."

65 Guha, "Not at Home in Empire." Guha's key examples are Kaye, History of the Indian Mutiny; Yeats-Brown, The Lives of a Bengal Lancer; and, crucially, Orwell, "Shooting an Elephant."

66 On the concept of the "uncanny" and colonial anxieties, see Padamsee, Representations of Indian Muslims; and Tickell, Terrorism, Insurgency and Indian-English Literature.

67 See also Bourke, "Fear and Anxiety."

68 For some recent studies of fear within the history of emotions, see Bourke, Fear; Laffan and Weiss, Facing Fear; and Plamper and Lazier, Fear Across the Disciplines.

69 Hofstadter, "The Paranoid Style."

70 Wagner, "Treading Upon Fires."

71 I have further developed this argument in Wagner, "Calculated to Strike Terror." 